\title{
A Study on the Level of Intercultural Knowledge among Malaysian Secondary School Students
}

\author{
Fatin Najwa Amelia binti Marsani \\ School of Languages, Literacies and Translation, Universiti Sains Malaysia, Penang, Malaysia \\ Manjet Kaur Mehar Singh (Corresponding author) \\ School of Languages, Literacies and Translation, Universiti Sains Malaysia, Penang, Malaysia \\ E-mail: manjeet@usm.my \\ Paramaswari Jaganathan \\ School of Languages, Literacies and Translation, Universiti Sains Malaysia, Penang, Malaysia \\ Ahmad Sofwan Nathan Abdullah \\ School of Languages, Literacies and Translation, Universiti Sains Malaysia, Penang, Malaysia \\ Premalatha Karupiah \\ School of Social Science, Universiti Sains Malaysia, Penang, Malaysia \\ Accepted: 11-07-2016 \\ doi:10.7575/aiac.ijalel.v.5n.6p.18 \\ Advance Access Published: September 2016 \\ URL: http://dx.doi.org/10.7575/aiac.ijalel.v.5n.6p.18
}

Received: 02-05-2016

Published: 01-11-2016

This research is funded by Fundamental Research Grant Scheme (FRGS), Ministry of Education, Malaysia.

\begin{abstract}
Malaysia is typified by three major ethnic groups namely Malay, Chinese and Indian. The evolution of national unity in Malaysia, which is based on acceptance and tolerance towards different cultures has been allowed to flourish in tandem with the realization of national aspirations. Even though education system is seen to be the best tool to cultivate team work among these three major ethnic groups, contemporary research reveals that there is still a lack of intercultural embedment in both tertiary and non-tertiary settings. Worst, non-tertiary setting national schools are seen as the breeding ground of racial polarization. Thus, the main objectives of this research is to explore the level of intercultural knowledge that can enhance intercultural awareness among Malaysian secondary school students. Data was collected using a structured survey questionnaire to elicit responses from Form Four students in one national secondary school in Penang, Malaysia on their level of intercultural knowledge. The results of this study shows low level of intercultural knowledge among secondary school students and it indicates poor intercultural awareness among them in the contexts of intercultural knowledge. This suggest that classroom intervention is needed to improve the students' intercultural knowledge and at the same time improve their intercultural sensitivity towards other cultures.
\end{abstract}

Keywords: intercultural awareness, intercultural knowledge, intercultural sensitivity, secondary school students

\section{Introduction}

Malaysia is a country that is by characterized by its cultural diversity due to its multi-ethnic population. Consequently, being a pluralistic society, Malaysia views unity as a crucial social glue that contributes towards fostering social cohesion and national harmony.

Malaysia is composed of three major ethnic groups and other minority ethnics. The major ethnic groups, namely the Malays constitute $50.1 \%$, of the overall population and who are homogenously Muslim. The other two major ethnic groups are the Chinese (22.6\%), who generally are either adherents of the Buddhist, Christian or Taoist faiths and lastly, the Indians $(6.7 \%)$, who though are predominantly Hindu, have sizeable minorities of Muslims and Sikhs. The Chinese community in Malaysia, for example uses a number of dialects including Hokkien, Hakka, Cantonese and Mandarin. For the Indian society, the language spoken is Tamil and for the Malay is Bahasa Melayu (Malaysia Demographic Profile, 2014).

The Malaysian social fabric is a veritable kaladeiscope of different customs, value systems and norms (Jamil, H., Abd. Razak., \& Nordin 2010) that have seamlessly congealed to form a uniquely diverse and complex ecosystem constrained as it is by communal strictures imposed by religious affiliation, cultural weltanschauungs, linguistic diversity and the demands of social conformity. Cognizant of this diverse reality and its rich heritage, successive leaders within the 
national political hierarchy have unveiled a series of initiatives that valorize egalitarianism and intercultural understanding as a means to socially engineer national unity within the prevailing communal diversity. Hence, visionary plans such as 'Bangsa Malaysia' (Malaysian Nation), 'Smart Partnership' (Mahathir 1991), 'One System for Malaysia' (Abdullah, 2004) and 'One Malaysia' (Najib, 2009), have primarily focused upon engendering equality between the different ethnic groups (Tong \& Robertson, 2008).

Since the Malaysian national schools topology is essentially constituted of these three dominant ethnic groups, a mirror image of the national demographic with all its attendant uniqueness and complexity is replicated particularly in national schools. As unity is one of the core national objectives since independence, it is one of the aims of Malaysian education system to encourage and improve social integration among these different ethnic groups in order to eliminate social prejudices and discrimination (Najeemah, 2008).

\section{Literature Review}

\subsection{Intercultural Knowledge Embedding via the National Education System}

Education plays an important role in constructing a socially cohesive society that celebrates unity in diversity. The government is cognizant of this reality as evidenced by its formulation of educational policies and frameworks that leverage upon education as a means to infuse intercultural understanding to unite their ethnically diverse polity. This mission is succinctly encapsulated in the Razak Report (1956) which outlines the core principles underlying Malaysian educational system, of which national unity and multi-racial harmony are deemed primary goals. Thus, policies that embed respect and that inculcate inter-ethnic tolerance and harmony amongst the national polity have been a common strand of educational planning since 1956. For instance, one of the targeted objectives of the National Education Policy is to unite Malaysia's plural society through the suffusion of a national identity and a commonality of purpose:

" To inculcate and nurture national consciousness through fostering common ideas, values, aspirations and loyalties in order to mould national unity and national identity in a multi-ethnic society” (Khader, 2012; p. 272)

Najeemah (2006) utilized a survey research methodology to investigate the patterns of social interaction between students of different ethnic groups in Malaysia. She found that students generally accorded unequal treatment to those from different ethnicities with some even displaying negative attitudes towards the Other. In addition, they were predisposed to behave along ethnic lines when forming study groups for discussion sessions or when seeking assistance. The study concluded with the ironic observation that when students from different ethnic backgrounds were gathered within a multiracial setting, they tended to differentiate and polarize. This theme of polarization is also apparent in numerous other studies (Mohd. Noor, Lee A. \& Omar, 2005; Stewart \& Langer, 2009; Wan, 1983) pertaining to intercultural relations in Malaysia. Essentially these studies in highlighting the low level of integration between the Malay and Chinese communities in Malaysia attributed this lack to the absence of social and cultural understanding (Wan, 1983) and the dearth of intercultural study material that facilitated intercultural knowledge embedding in both tertiary and non-tertiary settings (Mohd. Noor, Lee A. \& Omar, 2005; Stewart \& Langer, 2009).

In addition, this deficit in study material is further exacerbated by the adoption and utilization of foreign cultural constructs in local settings such as in the English Literature syllabus, that not only alienate learners but also the goal of promoting Malaysian multi-ethnic intercultural knowledge among students. In elucidating the former phenomena, Kaur (2002) and Gunakumaran (2003) attributed this alienation to the difficulty learners experienced in relating to foreign cultural practices/norms that were divergent from the practices/norms inherent in their own culture. For example, the association of black with death in Western culture constitutes an obvious antithesis to the association of white with death in Muslim societies thus implicitly truncating the formation of cross-cultural linkages for learners in Muslim societies like Malaysia.

In addition, to date, most research studies involving intercultural related issues in Malaysia have focused on the phenomena primarily in tertiary institutions due to the ethnically diverse campus environment (Maya, McLellan, Ngeow Y.M., Lean M.L., Wendy Y.M.T, 2010; Ramlee, Norzaini, Faridah, Abdul Razak \& Maimun, 2009) thus, neglecting secondary education and schools. A summary of the literature indicates one of the aims of the Malaysian education policies in bridging the unity gap among multi-ethnic groups in national secondary schools has not yet been achieved.

\subsection{Defining Intercultural Knowledge}

In general, intercultural knowledge refers to knowledge that facilitates understanding of cultures with different worldviews from one's own. Conceptually, intercultural knowledge is defined as a compendium of cognitive, affective, and behavioral knowledge and attitudes that support effective and appropriate interaction between different cultures in a variety of cultural contexts (Bennett, 2008). In postulating a similar definition, Judith and Nakayama (2004) in earlier work divided intercultural knowledge into three components with the first part composed of culture general knowledge that denotes an individual's familiarity with the patterns and constituents of other cultures. The second part is the culture self-knowledge component that postulates individual recognition of his own culture and the way he perceives it in relation to the Other. The final component is culture specific knowledge that refers to one's familiarity with the culture in question, including its social norms, values and history. 
The existential foundation of intercultural knowledge resides in a subset of skills termed as intercultural skills which encompasses listening, analyzing and relating pieces of information and meaningfully processing them (Bok, 2006). Matveev and Mitler (2004) noted that having a thorough intercultural knowledge is a crucial prerequisite for stimulating intercultural competency among secondary school students. Savicky (2008) proposed that such knowledge cannot be assumed and in building intercultural knowledge, a balance of theory, research and application is required. According to Kalantzis and Cope (2005), intercultural understanding identifies knowledge, skills, dispositions and behavior that assist students in developing and reacting with intercultural understanding at schools and in their lives outside schools. Through education, students are encouraged to engage with their own and others' culture, building both their sense of belonging and the flexibility to move between their world and world of others.

A similar concept of intercultural knowledge is also espoused by Bennett (2008). Within the framework of this study, intercultural knowledge is defined as a systematic way to classify one's own cultural patterns, getting used to unfamiliar ways of being whether empathically or flexibly by comparing and contrasting cultural patterns of others (Bennett, 2008). Lacking of intercultural knowledge will cause ethnocentrism, which is a condition where one thinks that one's culture is better than that of the Other and stereotyping towards other cultures. Therefore, this research intends to investigate the level of intercultural knowledge among Malaysian secondary school students.

\section{Methodology}

\subsection{Research Design}

Essentially, this study employed a quantitative survey in determining the respondents' intercultural knowledge. A purposive sampling technique was used to select 39 Form Four students from a national secondary school in Penang, Malaysia as respondents. This technique was deployed in order to obtain a cohort comprising different ethnic groups and to meet the criteria required and relevant to the research objective. The survey which was conducted in a Form Four classroom during the English language period, was monitored by the English Language teacher. On average, each respondent required approximately 20-30 minutes to complete the questionnaire. All respondents were requested to sign a students' consent form which authorized that any data collated be used solely for educational and research purposes. The document also provided assurances pertaining to the confidentiality of personal information.

\subsection{Measuring the Level of Intercultural Knowledge}

An adapted version of the Intercultural Knowledge and Intercultural Competence Value questionnaire instrument as developed by Bennett, Brown, Cartwright, Chung Gin, Davis, Deardorff, Hearn, Huston, Knefelkamp, Nishishiba and Smith (2009) for the American Colleges and Universities (AAC\&U) Intercultural Knowledge and Competence project was used with the relevant assessment scales modified to suit the purpose of this research study.

The questionnaire contained 20 questions and was divided into 2 sections. Section A was designed to elicit information pertaining to the respondents' personal particulars such as ethnicity, religion, gender, age and primary school background. Section B sought to evaluate the participants' intercultural knowledge in 4 different domains namely customs and traditions, traditional food, cultural beliefs and cultural practices. In each aspect, respondents were evaluated on their cultural self-awareness as well as their knowledge of other cultures. Respondents were graded according to the correct answers and overall mean score obtained by the respondents were graded according to the value rubric as mentioned below.

Table 1. Adapted version of Intercultural Knowledge and Competence Value Rubric (2009)

\begin{tabular}{|c|c|c|c|c|}
\hline $\begin{array}{l}\text { Intercultural } \\
\text { Knowledge }\end{array}$ & $\begin{array}{c}\text { POOR } \\
(1-5)\end{array}$ & $\begin{array}{c}\text { AVERAGE } \\
(6-10)\end{array}$ & $\begin{array}{l}\text { GOOD } \\
(11-15)\end{array}$ & $\begin{array}{c}\text { ADVANCED } \\
(16-20)\end{array}$ \\
\hline $\begin{array}{c}\text { Cultural Self } \\
\text { Awareness }\end{array}$ & $\begin{array}{l}\text { Shows minimal } \\
\text { awareness of own } \\
\text { cultural rules and } \\
\text { biases }\end{array}$ & $\begin{array}{l}\text { Identifies } \\
\begin{array}{l}\text { own } \\
\text { biases }\end{array}\end{array}$ & $\begin{array}{lr}\text { Recognizes r new } \\
\text { perspectives about own } \\
\text { cultural rules and } \\
\text { biases }\end{array}$ & $\begin{array}{l}\text { Articulates insights into } \\
\text { own cultural rules and } \\
\text { biases }\end{array}$ \\
\hline $\begin{array}{l}\text { Cultural } \\
\text { Worldview }\end{array}$ & $\begin{array}{l}\text { Demonstrates } \\
\text { surface } \\
\text { understanding of the } \\
\text { complexity of } \\
\text { elements important } \\
\text { to members of } \\
\text { another culture in } \\
\text { relation to its } \\
\text { history, values, } \\
\text { politics, } \\
\text { communication } \\
\text { styles, economy, or } \\
\text { beliefs and practices }\end{array}$ & $\begin{array}{l}\text { Demonstrates } \\
\text { partial } \\
\text { understanding of } \\
\text { the complexity of } \\
\text { the elements } \\
\text { important to } \\
\text { members of another } \\
\text { culture in relation } \\
\text { to its history, } \\
\text { values, politics, } \\
\text { communication } \\
\text { styles, economy, or } \\
\text { beliefs and } \\
\text { practices }\end{array}$ & $\begin{array}{l}\text { Demonstrates adequate } \\
\text { understanding of the } \\
\text { complexity of elements } \\
\text { important to members } \\
\text { of another culture in } \\
\text { relation to its history, } \\
\text { values, politics, } \\
\text { communication styles, } \\
\text { economy, or beliefs } \\
\text { and practices }\end{array}$ & $\begin{array}{l}\text { Demonstrates } \\
\text { sophisticated } \\
\text { understanding of the } \\
\text { elements important to } \\
\text { members of another } \\
\text { culture in relation to its } \\
\text { history, values, politics, } \\
\text { communication styles, } \\
\text { economy, or beliefs and } \\
\text { practices }\end{array}$ \\
\hline
\end{tabular}




\section{Results and Discussions}

Of the 39 subjects surveyed in this study, 43.6\% were Malay, 30.8\% Chinese and 20.5\% Indian. The remaining 5.1\% were of other races. The data reveal that that $56.4 \%$ of the respondents were Muslims, $20.5 \%$ were Buddhists, $15.4 \%$ were adherents of Hinduism, while $5.1 \%$ were Christians while $2.6 \%$ of the rest were followers of religions other than the aforementioned. In terms of primary school background, $94.9 \%$ of the respondents were formerly educated in from national primary schools while the remaining $5.1 \%$ of the respondents obtained their primary education from vernacular schools.

Analysis of the data compiled indicated that the respondents' level of intercultural knowledge varied according to the various cultural domains.

Table 2. Intercultural Knowledge of Customs and Traditions

\begin{tabular}{|c|c|c|c|}
\hline Cultural & Question & A ( $\%)$ & $\mathrm{B}(\%)$ \\
\hline \multirow{5}{*}{$\begin{array}{l}\text { Cultural } \\
\text { Customs } \\
\text { and } \\
\text { Traditions }\end{array}$} & $\begin{array}{l}\text { Q1: Generally, the Chinese community } \\
\text { their dead }\end{array}$ & $\begin{array}{l}\text { Bury } \\
(38.5)\end{array}$ & $\begin{array}{l}\text { Cremate } \\
(61.5)\end{array}$ \\
\hline & $\begin{array}{l}\text { Q2 : Vegetarian food is food that is } \\
\text { being prepared using }\end{array}$ & $\begin{array}{l}\text { Plant and vegetable } \\
\text { based ingredients } \\
(94.9)\end{array}$ & $\begin{array}{l}\text { A mix of plant, vegetable, } \\
\text { fish and meat ingredients } \\
(5.1)\end{array}$ \\
\hline & $\begin{array}{l}\text { Q3 : Feng Shui is a Chinese belief used } \\
\text { to arrange objects to enjoy harmony and } \\
\text { good luck }\end{array}$ & $\begin{array}{l}\text { Yes } \\
(94.9)\end{array}$ & $\begin{array}{l}\text { No } \\
(5.1)\end{array}$ \\
\hline & $\begin{array}{l}\text { Q4 : The Chinese in Penang commonly } \\
\text { used the dialect to communicate }\end{array}$ & $\begin{array}{l}\text { Hokkien } \\
(92.3)\end{array}$ & $\begin{array}{l}\text { Cantonese } \\
(7.7)\end{array}$ \\
\hline & $\begin{array}{l}\text { Q5 : The traditional dance of Kadazan } \\
\text { is }\end{array}$ & $\begin{array}{l}\text { Ngajat } \\
(28.2)\end{array}$ & $\begin{array}{l}\text { Sumazau } \\
(71.8)\end{array}$ \\
\hline
\end{tabular}

Table 2 shows the intercultural knowledge of the subjects regarding customs and traditions. Only $61.5 \%$ of the students answered Q1 correctly while 94.9\% answered Q2 and Q3 correctly. Finally, 71.8\% answered Q5 accurately. The overall result for this cultural aspect shows that students are aware of each other customs and traditions.

Specifically, questions regarding customs and traditions that are practiced by only one culture received higher scores (Q3-Q5). Comparing with Q1 with the lowest score (61.5\%) among other questions, respondents tend to get confused with other cultures that practices cremating and burying the dead. This proves that insufficient intercultural knowledge creates misunderstanding and indirectly misleading the respondents' idea on other cultures.

The respondents' intercultural knowledge of other cultures may be attributable to their primary school background whereby $94.9 \%$ of the respondents were from national type schools. This is supported by W.T Grant Consortium (1992) that exposure of differences and similarities in the cultures, religion and values that started from school indicates students' level of intercultural knowledge.

Although only $20.5 \%$ from the total percentage of participated respondents were Chinese, the findings show that the respondents are well aware of other cultures' custom and traditions. This implication is drawn from the fact that though the questions in this domain were essentially Sino-centric in orientation, they nevertheless elicited accurate responses from a cohort of which $79.5 \%$ were ethnically non-Chinese.

Table 3. Intercultural Knowledge of Traditional Dishes

\begin{tabular}{|c|c|c|c|}
\hline Cultural Aspect & Question & $\mathrm{A}(\%)$ & $\mathrm{B}(\%)$ \\
\hline \multirow{5}{*}{$\begin{array}{l}\text { Cultural Traditional } \\
\text { Food }\end{array}$} & $\begin{array}{l}\text { Q1: Are soy bean milk and longan herbal } \\
\text { drink of Chinese origin? }\end{array}$ & $\begin{array}{l}\text { Yes } \\
(69.2)\end{array}$ & $\begin{array}{l}\text { No } \\
(30.8)\end{array}$ \\
\hline & $\begin{array}{l}\text { Q2 : What food do Malay hawker usually } \\
\text { sell? }\end{array}$ & $\begin{array}{l}\text { Bird's nest soup \& } \\
\text { Bak kut the } \\
(5.1)\end{array}$ & $\begin{array}{l}\text { Tau Fu Fah \& Char } \\
\text { Kuey Teow } \\
(94.9)\end{array}$ \\
\hline & $\begin{array}{l}\text { Q3: Which of the following food } \\
\text { combinations are originally Chinese? }\end{array}$ & $\begin{array}{l}\text { Chicken rice \& } \\
\text { braised duck } \\
(94.9)\end{array}$ & $\begin{array}{l}\text { Nasi lemak \& Satay } \\
(5.1)\end{array}$ \\
\hline & $\begin{array}{l}\text { Q4 : String hoppers (putu mayam) is a } \\
\text { traditional food for the }\end{array}$ & $\begin{array}{l}\text { Malay } \\
(25.6)\end{array}$ & $\begin{array}{l}\text { Indian } \\
(74.4)\end{array}$ \\
\hline & $\begin{array}{l}\text { Q5 : A truly Malaysian breakfast } \\
\text { includes }\end{array}$ & $\begin{array}{l}\text { Roti Canai, Nyonya } \\
\text { Kuih \&Teh Tarik } \\
(100)\end{array}$ & $\begin{array}{l}\text { Sausages, cereals } \\
\text { and milk } \\
(0)\end{array}$ \\
\hline
\end{tabular}


Questions 1 to 4 in the Intercultural Knowledge of traditional food and their origins section were designed to test the students' ability in differentiating the origins of traditional food consumed by the three major racial groups in Malaysia. Generally, the respondents had difficulty in matching the traditional food and the origin as as majority provided incorrect answers. 30.8\% responded wrongly for Q1, 5.1\% responded wrongly for Q2 and Q3 and 25.6\% responded wrongly for Q4. In contrast, Q5 elicited a 100\% accurate response which is unsurprising given that as a multi-cultural country, respondents instinctively understood the implicative that a truly Malaysian breakfast comprises dishes that represents the three major ethnics in Malaysia.

Bennett (1998) suggested it is crucial to incorporate intercultural knowledge into the education system because it allows the students to see themselves as a part of others and increase their ability to compare and contrast their own culture with cultures of Others.

It is interesting to note that Q2 which was deliberately designed to further elucidate the nexus between religion and culture, yielded an inaccurate response from 5.2\% (N=2) of the respondents. This probably implies either a lack of knowledge regarding the religio-cultural nexus that underpins Malay cultural practices given that Islam prohibits the consumption of pork or a lack of sensitivity regarding that prohibition.

Table 4. Intercultural Knowledge of Cultural Beliefs

\begin{tabular}{|c|c|c|c|}
\hline Cultural & Question & $\mathrm{A}(\%)$ & $\mathrm{B}(\%)$ \\
\hline \multirow{6}{*}{$\begin{array}{l}\text { Cultural } \\
\text { Beliefs }\end{array}$} & $\begin{array}{l}\text { Q1: Believing in ghosts is a common } \\
\text { practice of Asians life }\end{array}$ & $\begin{array}{l}\text { True } \\
(82.1)\end{array}$ & $\begin{array}{l}\text { False } \\
(17.9)\end{array}$ \\
\hline & $\begin{array}{l}\text { Q2 : Purdah or veil is a garment worn by } \\
\text { Muslim women to }\end{array}$ & $\begin{array}{l}\text { Cover the hair only } \\
(12.8)\end{array}$ & $\begin{array}{l}\text { Cover the hair and } \\
\text { the face except the } \\
\text { eyes }\end{array}$ \\
\hline & & & $(87.2)$ \\
\hline & Q3 : The word merisik in Malay refers to & $\begin{array}{l}\text { A woman's marital status } \\
(5.1)\end{array}$ & $\begin{array}{l}\text { Seeking } \\
\text { engagement with an } \\
\text { unmarried woman } \\
(94.9)\end{array}$ \\
\hline & $\begin{array}{l}\text { Q4 : In Malay culture, black magic is } \\
\text { essentially practiced in order to }\end{array}$ & $\begin{array}{l}\text { Communicate with the } \\
\text { spirit world }\end{array}$ & $\begin{array}{l}\text { Word off illness or } \\
\text { cast spells } \\
(59.0)\end{array}$ \\
\hline & $\begin{array}{l}\text { Q5 : A Pontianak is the Malay equivalent } \\
\text { of }\end{array}$ & $\begin{array}{l}\text { A witch } \\
(15.4)\end{array}$ & $\begin{array}{l}\text { A vampire } \\
(82.1)\end{array}$ \\
\hline
\end{tabular}

Table 3 illustrates the results pertaining to the cultural beliefs domain. Generally, $82.2 \%$ respondents agreed that belief in the paranormal is a common phenomenon among Asians and this is corresponded with the percentage of respondents who answered Q5 correctly. Although $43.6 \%$ of the total respondents are Malays, it was obvious that they lacked cultural self-knowledge aspect as proposed by Judith and Nakayama (2004). This is evident from the responses to Q2, Q3 and Q4, which were entirely focused on the Malay cultural framework that implicitly indicate that even Malay subjects were unaware of their own cultural norms and practices.

Q2 assessed the respondents' knowledge on the term purdah with 87.2\% providing the correct answer. It is plausible that the remaining $12.8 \%$ mistakenly conflated purdah with hijab, a type of scarf worn by Muslim women to cover only their hair. However, a high percentage of $94.9 \%$ respondents managed to answer Q3 correctly wherein the culturally loaded term merisik was tested. The findings show that respondents were able to differentiate different terms in different cultures well if they are fully equipped with sufficient knowledge of the target cultures.

Through Q4, respondents' knowledge of cultural beliefs on black magic was tested and only 59\% of the respondents managed to answer Q4 correctly and $38.5 \%$ of the respondents answered wrongly. The remaining $2.5 \%$ of the respondents abstained from answering. This can be concluded that $41 \%$ of the total respondents have the wrong idea of black magic in the Malay culture. Such mislead idea will cause misunderstanding in the future if the respondents are not taught and informed of the appropriate intercultural information and knowledge. 


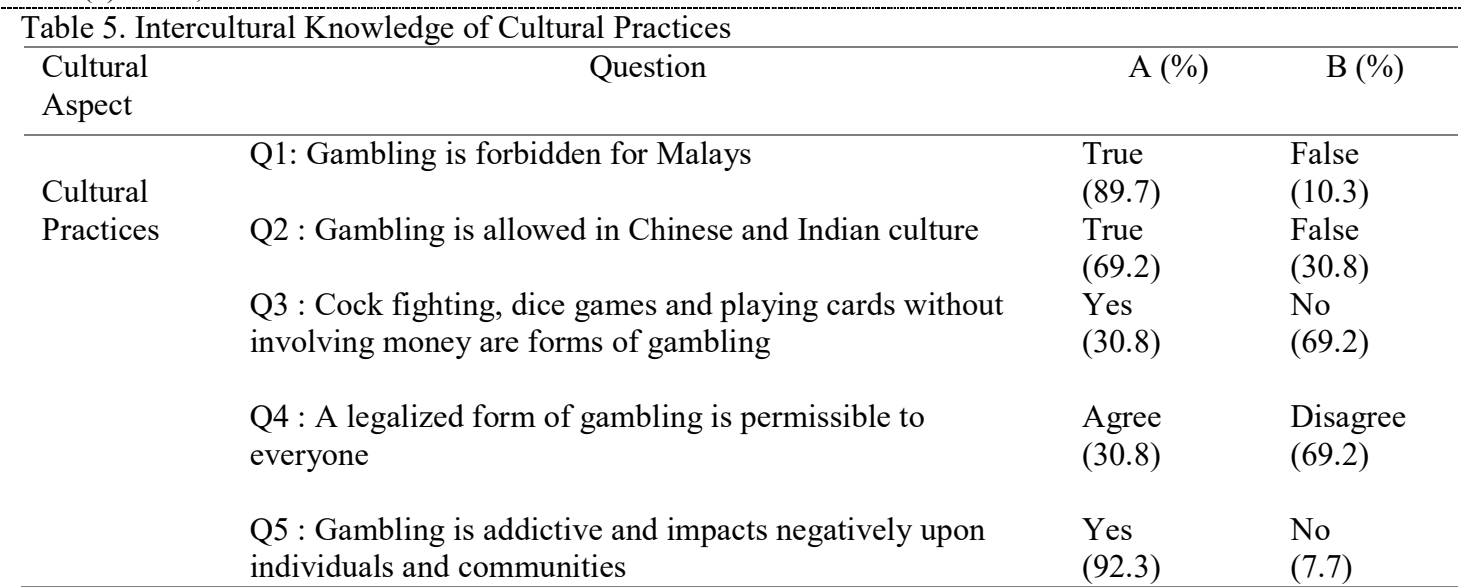

The last section of the questionnaire covered the domain of cultural practices and the result is as illustrated in Table 5 above. A salient feature of the findings is the dichotomy between the respondents' perceptions of gambling and their knowledge of its cultural permissibility. It is apparent that although $92.3 \%$ of the total respondents agreed that gambling wrought negative impacts to both individuals and society (Q5), they also suggested that it is allowed in certain cultures when 69.2\% agreed that gambling is allowed in Chinese as well as Indian cultures (Q2) while 10.3\% of the respondents suggested that gambling is permissible in Malay culture (Q1).

According to the results obtained from Q3 and Q4, respondents are seen as not having sufficient knowledge about the cultural practice when $30.8 \%$ of respondents answered these 2 questions wrongly. This concurs with Erikson (1964) that stated youth (between the age of 12 and 18 years), are usually disturbed and confused by clashes of cultural beliefs and cultural practices.

\section{Overall Results}

Generally, all items managed to get over $50 \%$ of the respondents to answer correctly. At the same time, only one item managed to get $100 \%$ of the respondents to answer correctly and the question focused on Malaysian as a whole (refer to Table 3 - Q5). This shows that respondents are still not able to differentiate cultural practices and beliefs either their own with others, or different cultures of others.

Table 6. Overall Mean Score of the Respondents

\begin{tabular}{lc}
\hline \multicolumn{1}{c}{ Cultural Aspect } & Mean Score \\
\hline Cultural Customs and Traditions & 4.13 \\
\hline Cultural Traditional Food & 4.18 \\
\hline Cultural Beliefs & 3.92 \\
\hline Cultural Practices & 3.38 \\
\hline Overall Mean & 15.62 \\
\hline
\end{tabular}

The mean score (4.18) of traditional food was the highest across the four domains followed by the customs and traditions domain (4.13), cultural beliefs domain (3.92) and lastly, the cultural practices domain (3.38). Overall mean score of the respondents reported was 15.62, which fell under good category as according to Intercultural Knowledge and Competence value rubric by Association of American Colleges and Universities (AAC\&U) (2009).

Respondents were known to be able to recognize new perspectives of own cultural rules and biases. In terms of cultural worldview, respondents were able to demonstrate adequate understanding of the complexity of elements important to other members of another culture in relation to its history, values, politics, communication styles, economy, or beliefs and practices.

As intercultural knowledge is interrelated with a person's intercultural understanding as described by Kalantzis and Cope (2005), it is pertinent to expose and equip students with intercultural knowledge since young. In Malaysian context, this can be effected via secondary school intercultural framework as it offers a conducive environment for intercultural exchange given that students spend almost half a day interacting with friends from different cultures in both formal learning settings and informal social settings.

This is supported by Rajyashree (2013), that there are a lot of benefits in representing a diverse world through literary texts. Such exposure can help them to practice their understanding based on their knowledge, which will then lead to unity among the students. Thus, in improving the secondary school students' level of intercultural knowledge, there is the need to expose them to cultural embedded reading material and school is seen to be the best place as it brings students of different races together at one ground.

\section{Limitations}

All in all, the findings of this study consist of enough strength that has made the research valid and informative. Firstly, the study involved respondents from different cultures and religions and hence, the findings were not biased in terms of racial compositions. Secondly, this research study was done in national secondary school in Penang whereby students 
are exposed to intercultural environments even outside classroom learning. Thus, students are exposed to other cultures and it is crucial for this research study to know that students are able to build their intercultural knowledge directly and indirectly through classroom learning and real life experiences. Thirdly, respondents were asked to answer the questionnaire without further discussion with their classmates and the session was held during English period and monitored by the teacher. Therefore, the results obtained were solely based on the respondents' knowledge without any help provided by their teacher or classmates.

The study were constrained by several limitations. First, the tool used in measuring respondents' intercultural knowledge consisted of questions related to four cultural domains. A more holistic instrument that included more cultural domains would be better equipped to glean a more comprehensive picture of the respondents' intercultural knowledge. Secondly, since the study was conducted in only one national secondary school, the results cannot be extrapolated to be representative of the level of intercultural knowledge among Malaysian secondary school students due to the small sample size.

\section{Future Direction}

It is recommended that future studies use a larger sample size and collate data from more national secondary schools in order to increase extrapolation Furthermore, a quantitative-qualitative methodology would generate not only more reliable data but also provide better insights on intercultural dynamics within Malaysian secondary school besides triangulating the outcome.

\section{Conclusion}

Bennett (1998) stated that it is crucial to incorporate intercultural knowledge into the core of education because intercultural knowledge allows the students see themselves as members of the community that shares the same future with others. However, the results obtained from this research study showed that students' level of intercultural knowledge when divided into different aspects, is still low and requires more attention even though the multi-cultural reality of Malaysia is highlighted in subjects taught in schools such as Moral Education (ME), Local Studies (LS) and History (Ministry of Education, 2000).

Thus, there is the need of better initiatives and intervention in Malaysian educational system in order to increase the level of secondary school students' intercultural knowledge. This is in line with the major goal of educational policy, which is to inculcate and nurture national consciousness through fostering common ideals, values, aspirations and loyalties in order to mould national unity and national identity in a multi ethnic society. The findings of this study will be used as the indicator in improving students' level of intercultural knowledge and initiates more research studies that will help in discovering ways to strengthen unity among the secondary school students based on adequate level of intercultural knowledge.

\section{References}

Balakrishnan, V. (2009). Teaching Moral Education in Secondary Schools Using Real-life dilemmas. Ph.D thesis submitted to the Victoria University of Wellington, New Zealand.

Bennett, M., \& Wurzel, J. (2004). Toward multiculturalism: A reader in multicultural education. Becoming Interculturally Competent, 62-77.

Bennett, J.M. (2008) Contemporary Leadership and Intercultural Competence: Understanding and Utilizing Cultural Diversity to Build Successful Organizations. Thousand Oaks, CA: Sage.

Bennett, Brown, Cartwright, Chung Gin, Davis, Deardorff, Hearn, Huston, Knefelkamp, Nishishiba and Smith (2009). Intercultural Knowledge and Competence value rubric by Association of American Colleges and Universities (AAC\&U). Retrieved from website: http://www.purdue.edu/cie/documents.PUPIL\%20handout.pdf

Bok, D. (2006). Our Underachieving Colleges: A Candid Look at How Much Students Learn and Why They Should be Learning More. Princeton: Princeton University Press.

Bhawuk, D. P. S., \& Brislin, R. (1992). The measurement of intercultural sensitivity using the concepts of individualism and collectivism. International Journal of Intercultural Relations, 16(4), 413-436.

Creswell, J. (2012). Educational Research: Planning, Conducting and Evaluating Quantitative and Qualitative Research (4th ed.). Upper Saddle River, New Jersey: Pearson Education.

Erikson, E.H. (1964). Insights and Responsibility. In Knowles R.T., Mc Lean G.F., Psychological Foundations of Moral Education and Character Development: An Integrated Theory of Moral Development. The Council for Research in Values and Philosophy.

Ganakumaran S., Shahizah Ismail Hamdan. Koo, Y. L. (2003). Pedagogical Implications of the Incorporation of the Literature Component in the Malaysian ESL Syllabus, Teaching Literature in ESL Syllabus, Teaching Literature in ESL/EFL Contexts. Petaling Jaya: Sasbadi.

Hofstede, G. (n.d.). Culture and Organization: International Studies of Management and Organization (4th ed., Vol. 10, pp. 15-41). M.E Sharpe.Inc.

Holliday, A. (2013). Investigating Culture. In Understanding Intercultural Communication. Routledge. 
Jamil, Hazri, Abd. Razak \& Nordin. (2010). Ethnicity and education policy in Malaysia: Managing and mediating the ethnic diversity. Journal of US-China public Administration. 7(1), 77-87.

Jamil, H. (2004). Ethnic Interaction among Students in Secondary Schools in Malaysia. Pulau Pinang : School of Educational Studies. Universiti Sains Malaysia.

Jamil, H., \& Raman, S. (2012). Malaysian Educational Policy for National Integration: Contested Terrain of Multiple Aspiration. Journal of Language and Culture, 3(1), 20-31. doi:10.5897/JLC11.025

Judith, N.M., \& Nakayama,T.K., (2004). Intercultural Communication in Context. New York, NY:McGraw Hill.

Kalantzis, M. \& Cope, B. (2005). Learning by Design. Common Ground Publishing, Melbourne.

Kaur, G., (2002) Literature in Language Classroom. In Kaur G. (2003) Teaching Literature in ESL Syllabus, Teaching Literature in ESL/EFL Contexts. Petaling Jaya: Sasbadi.

Khader, F. (2012). The Malaysian Experience in Developing National Identity, Multicultural Tolerance and Understanding through Teaching Curricula: Lessons Learned and Possible Applications in the Jordanian Context. International Journal of Humanities and Social Science, 2(1).

Khemlani, M. (2010). Ethnic Relations and Nation Bulding: The Way Forward. Strategic Information and Research Development Centre.

Langer, A., Abdul Raufu, M., Stewart, F. (2009) Diversity and Discord: Ethnicity, Horizontal, Inequalities and Conflict in Ghana and Nigeria. Journal of International Development 21, 477-482.

Matveev, A. V., \& Milter, R. G. (2004). The value of intercultural competence for performance of multicultural teams. Team Performance Management, 10(5/6), 104-111.

Malaysia Demographics Profile 2014. (n.d.). Retrieved December 15, 2015, from http://www.indexmundi.com/malaysia/demographics_profile.html

Maya, K.D., Mc Lellan, J., Ngeow, Y.M., Lean, M.L., Wendy, Y.M.T., (2010) Ethnic Relation and Nation Building: The Way Forward. SIRD: Petaling Jaya.

Ministry of Education (2000). Malaysia: Education for All. Ministry of Education, Kuala Lumpur.

Mohd Noor, M, .Lee Abdullah, M. A., \& Omar, R. (2004). Hubungan etnik di Malaysia: Satu sorotan ringkas. In Roziah Omar and Sivamurugan Pandian (Eds.), Malaysia Isu-Isu Sosial Semasa (pp. 170-179). Kuala Lumpur: Institut Sosial Malaysia.

Mohd. Yusof, N. (2006). Patterns of Social Interaction between Different Ethnic Groups in Malaysian Secondary Schools. Jurnal Pendidik Dan Pendidikan, 21, 149-164.

Najeemah, Y. (2008). Multicultural education: managing diversity in Malaysian schools. Malaysian Education Deans Council Journal, 2.

Najeemah, Y. (2006). Patterns of Social Interaction between Different Ethnic Groups in Malaysia. Jurnal Pendidik dan Pendidikan, 21, 149-164.

Ramlee, M., Norzaini, A., Faridah, K., Abdul Razak, A., Maimun, A.L. (2010). Social Integration among Multi-Ethnic Students at Selected Malaysian Universities in Peninsular Malaysia: A Survey of Campus Social Climate, ASEAN Journal of Teaching and Learning in Higher Education 1, 35-44.

Rahimah, H.A (1998). Educational Development and Reformation in Malaysia: Past, Present, and Future. Journal of Educational Administration 36 (5).

Rajyashree K.L. \& Urjani, C. (2013). A Pragmatic Study of Intercultural Communication in Kiran Desai. Pertanika Journal of Social Sciences \& Humanities, 21 (1), 351-361.

Savicky, V. (2008). Developing Intercultural Competence and Transformation: Theory, Research, and Application in International Education. Sterling, VA: Stylus Publishing LLC.

Stier, J. (2006). Internationalisation, Intercultural Communication and Intercultural Competence. Journal of Intercultural Communication, (11).

Tong, M. C. \& Robertson K. (2008). Political and Cultural Representation in Malaysian Websites. Intercultural Journal of Design. 2(2), 67-69.

Wan Hashim, W.T. (1983) Race Relations in Malaysia. Heinemann Educational Books (Asia) LTD. Kuala Lumpur.

W.T. Grant Consortium (1992) School Based Social Competence. 